DOI: $10.22559 /$ folklor.978

Folklor/edebiyat, cilt:25, say1: 97-1, 2019/1

\title{
İlkokul 3. Sınıf Öğrencilerinin Kaygı ve Depresyon Düzeylerinin İncelenmesi
}

\author{
A Study on Anxiety and Depression Levels of Primary School Third Grade \\ Students
}

\begin{abstract}
Ülkü Tosun*
Aziz Zorlu**

$\ddot{O} \mathbf{z}$

İlkokula yeni başlayan bazı öğrencilerin yaşadığı okula uyum sorunları daha üst sınıflarda kaygı ve depresyon belirtileri şeklinde devam ederek öğrencilerin akademik başarılarını, arkadaşlarıyla ilişkilerini, sınıf içi davranışlarını etkileyebilmektedir. Bu çalışmanın amacı, ilkokul 3. sınıf öğrencilerinin kaygı ve depresyon düzeylerinin hem kendi algıları hem de velilerinin algıları doğrultusunda belirlenmesidir. İstanbul'da ilkokulda okumakta olan 207 üçüncü sınıf öğrenci ve velilerine ayrılık kaygısı, genel kaygı, panik bozukluk, fobi, OKB, depresyon alt testlerinin olduğu Çocuklar için Kaygı ve Depresyon Ölçeği uygulanmıştır. Nicel araştırma yöntemi ve tarama modelinin uygulandığı çalışmada ayrılık kaygısı $(\mathrm{p}=.044)$ ve panik bozuklukta $(\mathrm{p}=.018)$ kızlar ve erkekler arasında erkekler aleyhine anlamlı farklılıklar bulunmuştur. Velilerin kendi çocuklarını değerlendirmelerinde, kızlar ve erkekler açısından anlamlı bir farklılık yoktur. Tüm alt testler açısından incelendiğinde erkek öğrenciler \%1.1- \%10.9, kız öğrenciler \%3.4 - \%10.1 arasında değişen oranlarda sinır düzeyde rahatsızlığa sahip olduklarını bildirirlerken, yüksek düzeyde rahatsızlığa sahip olduğunu bildiren erkek öğrencilerin oranı \% 4.3 - \%12, kız öğrencilerin ise \% 1.1- \%6.7 arasında değişmektedir Sonuçta erkek ve kız öğrencilerin kaygı düzeyleri birbirine yakındır ve sınırda görülen kaygı oranları da alanyazındaki diğer araştırmalarla örtüşmektedir. Fakat her iki gruptaki yüksek kaygı oranları, öğrencilerin rehberlik
\end{abstract}

\footnotetext{
${ }^{*}$ Kıbrıs Sosyal Bilimler Üniversitesi Eğitim Fakültesi Rehberlik ve Psikolojik Danışmanlık ABD, ulku.tosun@kisbu.edu.tr

*** Milli Eğitim Bakanlığı Rehberlik, azizzorlu@hotmail.com
} 
servisinden bireysel ve/veya grup çalışmaları şeklinde psikolojik destek almalarının gereğine işaret etmektedir.

Anahtar sözcükler: öğrenci, kaygl, fobi, panik bozukluk, OKB, depresyon

\begin{abstract}
The school adaptation problems of some primary school first grade students can affect their academic successes, friend relationships, classroom behaviors in the higher grades the reason is because their adaption problems can turn to the symptoms of anxiety and depression. The aim of this study is to determine the level of anxiety and depression of primary school third graders both in terms of their own perceptions and their parents' perceptions. Anxiety and Depression Scale For Children consisting of 6 subscales as separate anxiety, general anxiety, panic disorder, phobia, OCB, depression was administered to 207 third grade students and their parents of primary school in Istanbul. In this study, qualitative method and survey model were used and significant differences were found between girls and boys against boys, in terms of separate anxiety ( $\mathrm{p}=.044)$ and panic disorder ( $\mathrm{p}=.018)$. There was no significant difference between girls and boys in terms of their evaluations of their parents. When all subscales examined, rates ranging from $1.1 \%$ to $10.9 \%$ for boys and ranging from $3.4 \%$ to $10.1 \%$ for girls were reported to have borderline level disorders, while high level disorder rates changed from $4.3 \%$ to $12 \%$ for boys, from $1.1 \%$ to $6.7 \%$ for girls. As a result, the anxiety levels of boys and girls were close to each other and the ratios of borderline level disorders seemed to overlap the results of previous studies. High anxiety proportions of both groups highlighted the need for students to receieve psychological support from the school guidance service in form of individual and/or group works.
\end{abstract}

Keywords: student, anxiety,phobia, panic disorder, $O C B$, depression.

\title{
Giriş
}

İlkokul birinci sınıf öğrencileri, ailelerinden ayrılarak ve bireysel olarak okula gelirler. Bazılarında uyum sorunları olabileceği öngörüsüyle üst sınıflardaki öğrencilerden bir hafta önce okula başlayarak uyumlanma sürecini yaşamaları sağlanır. Bazı öğrencilerdeki uyum sorunları daha üst sınıflarda kaygı ve depresyon belirtileri şeklinde devam ederek öğrencilerin akademik başarılarını, arkadaşlarıyla ilişkilerini ve sınıf içi davranışlarını etkileyebilir. Hafif ve orta derecedeki kaygılar; öğrenme ve performansı olumlu yönde etkilerken, kronik ya da şiddetli kaygılar kişide uyumsuzluğa neden olarak kaygı bozukluğu rahatsızlıklarına yol açabilir.

\section{Çalışmanın amacı:}


Çalışmanın amacı, ilkokul 3. sınıf öğrencilerinin kaygı ve depresyon düzeylerinin hem kendi algıları hem de velilerinin algıları doğrultusunda belirlenmesi ve daha sonra sinırda ve/veya yüksek kaygı ve depresyon bozuklarından bir veya daha fazlasına sahip öğrencilere bireysel destek verilmesinin sağlanmasıdır.

\section{Kuramsal çerçeve}

Kayg1; bireyin var olmak, hayatta kalmak için verdiği çabalardan oluşur. Varoluşçu kuram, normal kaygı ile nevrotik kaygıyı ayırır ve normal kaygının bireysel gelişimi desteklediğini savunur. Normal kaygı, olaylarla uyumludur, kişiyi motive eder, fazla tehdit edici olmadığından bastırılması da gerekmez. Varoluşçu kaygı, normal kaygının bir şeklidir. Nevrotik kaygı ise yıkıcıdır, kişiyi işlevsizleştirir ve bastırılma eğilimindedir. Kişinin psikolojik olarak sağlıklı olabilmesi normal kaygıyı kabullenmesi ve başa çıkabileceği oranda nevrotik kaygı hissetmesiyle ilgilidir (Yalom, 1999; Corey, 2005: Murdock, 2014). May ve Yalom (2005) kaygının "insanoğlunun hayatta kalma, yaşamını sürdürme, varlığına anlam katma ihtiyacından kaynaklandığını" belirtirler (Akt. Murdock, 2014). Araştırma sonuçlarına göre çocuk ve ergenlerde kaygı bozukluklarını yaygınlık oranı dünyada \%5 'tir. Ülkemizde ise çocuklarla ilgili araştırmalar doğrudan kaygı bozuklukları üzerine değil, daha çok sosyal kaygı, zorbalık, anne-baba tutumları gibi alanlar üzerindedir (Seçer ve Gülbahçe, 2013). İlkokul öğrencilerinin bazılarında görülen okul korkusu yakınması önceleri çocukluktaki kaygı olarak değerlendirilirken son zamanlarda uyum bozukluğu, fobi, depresyon gibi pek çok bozukluğun belirtisi olarak kabul edilmektedir (Özcan, Kılıç ve Aysev, 2006). Çocuğun okuldan korkmasını ifade eden okul fobisi terimi, ilk kez 1941 yılında kullanılmıştır. Alanyazındaki çalışmalara göre, okul fobisi ile cinsiyet ve ailenin SES'i arasında herhangi bir bağlantı yokken, okulun reddi ile kaygı bozuklukları arasında bağlantılar mevcuttur (Bahalı, Tahiroğlu ve Avc1, 2009).

Ailelerde strese neden olan olaylar, çocukların gelişimini kısa ve uzun vadede etkilerler. Çocuklar, psikolojik dengeleri bozulduğunda şu davranışlardan bazılarını sergilerler: Akademik başarısızlık, arkadaşlar sorunlar, öfke, yalnızlık, karşı gelme, kaygı, okul reddi vb. (Ertürk, ve Gül, 2006). Güncel ve gerçek psikososyal stres faktörlerinin etkisiyle çocukta kaygı bozuklukları başlayabilir (Güleç,2006). Nörotik kaygı bozuklukları olanlar çevrelerine 
karş1 uyumsuzdurlar. Bununla birlikte tehlikeli olmazlar veya gerçeklikten kopuk değildirler (Butcher, Mineka ve Hooley, 2013).

DSM-5 tanı kriterleri kaynaklarına göre ayrılık kaygısı, panik bozukluk, fobi, sosyal fobi, yaygın/genel kaygı bozukluğu, kaygı bozuklukları kategorisinde yer alırken daha önceleri kaygı bozuklukları altında tanılanan takıntı-zorlantı / obsessif-kompulsif bozukluk (OKB), ve duygudurum bozukluklarında yer alan depresyon bozuklukları, bağımsız kategoriler olarak değerlendirilmişlerdir. $\mathrm{Bu}$ da son dönemlerde bu alanlardaki rahatsızlıkların arttı̆̆1 ve çeşitlendiği şeklinde yorumlanabilmektedir (DSM-5, 2013).

Kaygı bozuklukları çocuklar arasında yaygındır. Kızlarda erkekler arasında olduğundan daha yaygın olarak görülür. En yaygın görülen "ayrılık kaygısı” bozukluğu çocukların \% 2'sinde bulunur (DSM-4, 2000). Araştırmalara göre, çocukların kaygı ve depresif bozukluklarının eşzamanlı olduğu görülür (Manassis ve Monga,2001). Genelleştirilmiş kaygı bozukluğu yetişkinler gibi çocuklarda da bulunur. Bu çocuklar aşırı duygusal, utangaç ve çekingen olabilirler. Uyku sıkıntıları ve okul korkuları olabilir. Annelerine aşırı bağımlı olabilirler (Butcher, Mineka ve Hooley, 2013).

Ayrılık kaygısı olan çocuklar kabuslar görürler, gerçekçi olmayan korkuları vardır, okula başlamaları, okulda yalnız kalmaları kolay olmaz. (Bourne,2010). Bir kaygı bozukluğu yaşayan kişi, eş zamanlı olarak bir başka kaygı bozukluğu çeşidi veya depresyon da yaşayabilir (Butcher, Mineka ve Hooley, 2013) . Bu nedenle bozuklukların temelinde önemli benzerlikler olduğu öngörülebilir. Çevrelerini ya da duygularını denetleyemediğini düşünen insanlarda kaygı bozukluğu görülme olasılığı yüksektir. Hayvan, dişçi fobileri gibi rahatsızlıklar, çocuklukta başlar ve koşullanma yoluyla fobi haline gelebilir. Takıntı-zorlantı/ obsessif-kompulsif durumlara çocuklarda sık rastlanır ve aşırı olmadıkları sürece de doğal kabul edilir. Yetişkin olduklarında, OKB belirtilerinin çoğu kaybolur (Akgün,1989). Takıntı; kişinin kendi isteği dışında bilinç alanına zorla giren düşüncelerdir. Zorlantı ise, takıntılı düşüncelerden kurtulmak için kişinin sergilediği davranışlardır. Çocuklarda zorlantılar daha ön plandadır. İlkokul çocuklarında en çok görülen zorlantılar sayma ve simetridir (Mukaddes, 2001).

Çocuklarda depresyon; ağlama, göz temasından kaçınma, iştahsızlık, saldırgan davranışlar olarak görülebilir. 13 yaş altında depresyon görülme sıklığı \%2.8 oranı ile yüksek olarak nitelenir. Çocuklukta anne-babanın depresyonda olması ile çocuk depresyonu arasında ilişki 
bulunmaktadır. Çocuklar, çevrelerinden görerek öğrenme ya da kültürel nedenlerle depresif olabilirler (Yüksek, 2006; Bourne, 2010).

Kaygı, fobi, takıntı-zorlantı bozuklukları Ankay (2013) tarafından çocuklarda yaygın olarak görülen nörotik bozukluklar olarak kategorize edilirler.

\section{Problem}

İstanbul'daki ilkokul 3. sınıf öğrencilerinin kayg1 ve depresyon düzeylerinin hem kendileri hem de velileri tarafından değerlendirilmelerinin karşılaştırmalı olarak incelenmesidir.

\section{Alt problemler}

- Öğrenci algıları açısından ayrılık kaygısının ve panik bozukluğun cinsiyete göre karşılaştırılması

- Depresyon alt ölçeğine göre öğrenci ve veli algılarının karşılaştırılması

\section{Yöntem}

$\mathrm{Bu}$ çalışma, nicel araştırma yöntemlerinden betimsel nitelikte ve tarama modeli olarak desenlenmiştir (Büyüköztürk, Çakmak, Akgün, Karadeniz ve Demirel, 2011). Tarama modeli, bireylerin ve grupların yetenekler, tercihler, davranışlar gibi özelliklerinin belirlendiği ve diğer araştırmalara göre daha fazla katılımcının yer aldı̆̆ı araştırma modelidir (Karasar, 2000; Baştürk, 2011).

\section{1. Çalışma grubu:}

2016-2017 eğitim öğretim yılında İstanbul'da ilkokula devam eden 102 erkek, 105 k1z öğrenci toplam 207 öğrenciden oluşan 3. sınıfların tamamını kapsamaktadır. Çalışma grubu; seçkisiz olmayan örnekleme yöntemlerinden biri olan uygun örnekleme tekniği ile belirlenmiştir. Uygun örnekleme tekniğinde, en ulaş1labilir ve en fazla tasarruf sağlayan durum söz konusudur (Büyüköztürk ve diğ., 2011).

\section{Veri toplama aracı : çocuklar için kaygı ve depresyon ölçeği (çadö)}

2000 yılında Chorpita ve arkadaşları tarafından geliştirilen ÇADÖ, 2017 yıkında Görmez ve arkadaşları tarafından Türkçe'ye uyarlanmıştır. 47 maddeden oluşan ölçeğin, ayrılık kaygısı, genel kaygı, panik bozukluk, fobi, obsessif-kompulsif bozukluk, depresyon 
olmak üzere 6 alt testi vardır. Ölçeğin Cronbach Alfa güvenirlik katsayısı genel olarak .95, olurken her bir alt test için yapılan analizlerde de .75-.86 arasında değişmektedir.

\section{Verilerin analizi :}

SPSS-23 bilgisayar programıyla yapılan veri analizlerinde çalışma grubunda normal dağılım görülmediğinden non-parametrik istatistik teknikleri kullanılmıştır (Büyüköztürk, 2006).

Ölçekten elde edilen veriler sıralama ölçeği düzeninde olduğu için istatistiksel işlemlerde frekanslar, çapraz frekans tabloları, ilişkili iki ölçüm setine ait puanlar arasındaki farkın anlamlılığını test etmek amacıyla uygulanan Wilcoxon işaretli sıralar testi, tek değişkenli ve iki değişkenli ki-kare testleri uygulanmıştır. Ayrıca öğrencilerin kendilerini değerlendirmeleriyle velilerin öğrencileri değerlendirmesi arasındaki ilişki için Spearman korelasyon analizi yapılmıştır (Büyüköztürk, 2006; Seçer, 2013).

\section{Bulgular ve tartışma}

Uygulanmış olan tüm alt testler açısından genel olarak bakıldığında erkek öğrenciler \% 1.1 - \%10.9, k1z öğrenciler \%3.4 - \%10.1arasında değişen oranlarda sınır düzeyde rahatsızlığa sahip olduklarını bildirirlerken, yüksek düzeyde rahatsızlığa sahip olduğunu bildiren erkek öğrencilerin oranı \% 4.3-\%12, k1z öğrencilerin ise \%1.1-\%6.7 arasında değişmektedir. Kaygı düzeyleri birbirine yakın olan kız ve erkek öğrencilerin kaygı düzeyleri alt testlerinin sonuçları açısından alanyazındaki diğer araştırmalarla örtüşmektedir. İlkokul çağında görülen kaygı bozuklukları çeşitlerinde yaygınlık oranları \% 2.6 - \%10 arasında değişen oranlarda yaygınlık göstermektedirler (Mukaddes, 2001). Yurtbay (1997, Akt. Özcan ve Aysev, 2009) 10-11 yaşlarındaki çocukların \% 16 'sında kaygı bozukluklarının yaygın olduğunu vurgular. Kaygı bozukluklarının yaşam boyunca kişilerde yaygın olarak görülme oranları Arkonaç'a göre (1989) \% 25, Öztürk ve Uluşahin'e göre (2011) \% 13.6 - 28.8 oranları arasında değişmektedir. 
Öğrenci algılarına göre kaygı ve depresyon bozuklukları alt testlerinin değerlendirmeleri

\begin{tabular}{|c|c|c|c|c|}
\hline & & Erkek \% & Kız \% & Toplam \% \\
\hline \multirow{2}{*}{ Ayrılık Kaygısı } & Sinırda & 8.7 & 3.4 & 6.1 \\
\hline & Yüksek & 8.7 & 2.2 & 5.5 \\
\hline \multirow[t]{2}{*}{ Genel Kaygı } & Sinırda & 6.5 & 4.5 & 5.5 \\
\hline & Yüksek & 4.3 & 1.1 & 2.8 \\
\hline \multirow{2}{*}{ Panik Bozukluk } & Sinırda & 1.1 & 10.1 & 5.5 \\
\hline & Yüksek & 12.0 & 6.7 & 9.4 \\
\hline \multirow[t]{2}{*}{ Fobi } & Sinırda & 0.0 & 0.0 & 0.0 \\
\hline & Yüksek & 5.4 & 2.2 & 3.9 \\
\hline \multirow[t]{2}{*}{ OKB } & Sinırda & 10.9 & 8.6 & 5.3 \\
\hline & Yüksek & 7.6 & 3.4 & 5.5 \\
\hline \multirow[t]{2}{*}{ Depresyon } & Sinırda & 4.3 & 5.6 & 5.0 \\
\hline & Yüksek & 4.3 & 0.0 & 2.2 \\
\hline
\end{tabular}

Velilerin algılarına göre kaygı ve depresyon bozuklukları alt testlerinin değerlendirmeleri

Tablo2.

Veli Algılarına Göre Kaygı Bozukluğu Çeşitlerinin Yüzdelik Dă̆ılımları

\begin{tabular}{lllll}
\hline & & & & \\
\hline \multirow{2}{*}{ Ayrılık Kaygısı } & Sinırda & 5.7 & 9.2 & Toplam \% \\
\cline { 3 - 3 } Genel Kayg1 & Yüksek & 8.6 & 3.9 & 7.5 \\
& Sinırda & 0.0 & 1.3 & 6.2 \\
Panik Bozukluk & Yüksek & 1.4 & 7.9 & 0.7 \\
& Sinırda & 2.9 & 0.0 & 4.8 \\
Fobi & Yüksek & 2.9 & 9.2 & 1.4 \\
& Sinırda & 4.3 & 2.6 & 6.2 \\
OKB & Yüksek & 2.9 & 5.3 & 3.4 \\
& Sinırda & 11.4 & 6.6 & 4.1 \\
Depresyon & Yüksek & 14.3 & 7.9 & 8.9 \\
& Sinırda & 4.3 & 6.6 & 11.0 \\
& Yüksek & 7.1 & 3.9 & 5.5 \\
\hline
\end{tabular}

Öğrencilerin algılarına göre panik bozukluk ile OKB de görülen en yüksek oranlar, velilerinin değerlendirmeleriyle göreceli olarak örtüşebilmektedir. Örneğin: Sinır düzeydeki kayg1 erkeklerde; hem öğrencilere OKB (\% 10.9) hem de velilere göre OKB (\% 11.2), kızlarda öğrenciler açısından panik bozukluk (\%10.1), farklı olarak veliler açısından ayrılık kaygısıdır (\%9.2) şeklindedir. Fakat yüksek düzeydeki kaygıların değerlendirilmesi erkekler için hem öğrenciler (\%12) hem de veliler (\%14.3) tarafından OKB olarak ifade edilirken, kızlar için de hem öğrenciler (\%6.7) hem de veliler (\%9.2) tarafindan panik bozukluk olarak kabul edilmektedir. 
Kızlarda ve erkeklerde yüksek oranlarda görülen $\mathrm{OKB}$, çeşitli araştırmalara göre erkek ve kadınlarda bazen eşit bazen de farklılık göstermektedir (Yaluğ ve diğ.,2003). En sıklıkla görülen $\mathrm{OKB}$, kirlenme ve mikrop bulaşma korkusudur (Türkbay ve diğ.,2000). Kendine ve sevdiklerine zarar geleceği korkusu da yaygın obsesyon/takıntılardandır (Akgün,1989). Çocuklar ve ergenlerin OKB belirtilerini sakladıkları ve çoğunun da OKB yerine depresyon ya da kaygı bozukluğu tanısı aldığı görülebilmektedir (Demir ve diğ., 2000). Bu nedenle OKB belirtilerinin ölçekler uygulanarak incelenmesi çocukların yaşadıkları sorunların daha doğru olarak saptanmasına katkıda bulunabilecektir.

İlkokul 3. sınıf öğrencilerinin "genel kayg1, ayrılık kaygısı, depresyon, panik b., fobi, OKB" alt testleri ve "toplam kaygı" ve " toplam kaygı ve depresyon" düzeylerine ilişkin kendilerinin değerlendirmelerinde, yalnızca ayrılık kaygısı $(\mathrm{p}=.044)$ ve panik bozuklukta $(p=.018)$ kızlar ve erkekler arasında $p<.05$ düzeyinde istatistiksel olarak anlamlı farklılıklar bulunmuştur.

\section{Öğrenci algıları açısında ayrılık kaygısının cinsiyete göre incelenmesi}

\section{Tablo 3}

Öğrenci Algılarına Göre Ayrılık Kaygısı Ki-Kare Sonuçları

\begin{tabular}{lccccc}
\hline \multicolumn{5}{c}{ Ayrılık Kaygisı } \\
\hline Cinsiyet & & Yok & Sinırda & Yüksek & Toplam \\
\hline \multirow{2}{*}{ ERKEK } & $\mathrm{N}$ & 76 & 8 & 8 & 92 \\
& $\%$ & 82.6 & 8.7 & 8.7 & 100 \\
KIZ & $\mathrm{N}$ & 84 & 3 & 2 & 89 \\
& $\%$ & 94.4 & 3.4 & 2.2 & 100 \\
\hline$\chi$ & $\%=6.225$ & $\mathrm{sd}=2$ & $\mathrm{p}=.044$ & &
\end{tabular}

Ayrılık kaygısı, çocuklara özgü bir bozukluk olarak kabul görür ve belirtisi çocuğun okula gitmeyi reddetmesidir (Seçer ve Gülbahçe, 2013). Çocuk ve ergenlerdeki yaygınlık oranının kız ve erkeklerde genelde benzeştiği ve \% 3-5 arasında olduğu tahmin belirtilmektedir (Austin ve Sciarra, 2012). Bununla birlikte klinik ortamlarda erkeklerde görülme oranı kızlardan daha yüksektir (Özcan ve diğ., 2006; Özcan ve Aysev, 2009; Bahalı ve diğ., 2009). Bu çalışmada da testin uygulanması, normal ortamlardaki yalnızca gözlemlere dayalı değerlendirmelerden daha farklı bilgi alınmasını sağlayarak, sonuçlar klinik ortamlardaki sonuçlar ile örtüşmüştür. Bazı araştırmalarda ailede ilk doğan çocukta ayrılık kaygısı görülme olasılığının yüksek olduğu yorumu yapılmakla birlikte, bu kanı her zaman doğrulanamamıştır (Akgün, 1989; Bahalı ve diğ., 2009). Bu çalışmada da yalnızca üç erkek öğrenci ile bir kız öğrenci ailenin ilk çocuğudur. 


\section{Öğrenci algıları açısında panik bozukluğun cinsiyete göre incelenmesi}

\section{Tablo 4}

Öğrenci Algılarına Göre Panik Bozukluk Ki-Kare Sonuçları

\begin{tabular}{lccccc}
\hline \multicolumn{6}{c}{ Panik Bozukluk } \\
\hline Cinsiyet & Yok & Sinırda & Yüksek & Toplam \\
\hline \multirow{2}{*}{ ERKEK } & $\mathrm{N}$ & 80 & 1 & 11 & 92 \\
& $\%$ & 87 & 1.1 & 12 & 100 \\
KIZ & $\mathrm{N}$ & 74 & 9 & 6 & 89 \\
& $\%$ & 83.1 & 10.1 & 6.7 & 100 \\
\hline$\chi=8.057$ & $\mathrm{sd}=2$ & $\mathrm{p}=.018$ & &
\end{tabular}

Araştırmalara göre kadınlarda daha fazla görülen panik bozukluk (Yaluğ ve diğ., 2003), bu çalışmada da benzer bir sonuç sergilemiştir. Nolen-Hooksema (2011) insanların 3/5 'inin yaşamlarının bir döneminde panik bozukluk yaşadıklarını, yetişkinlerde bu oranın \% 28 olduğunu vurgular. Alanyazında çocukların kaygı bozukluğu olmasının nedenleri kalıtım ve çevre olarak gösterilir. Çevre, öncelikle aile çevresidir ki çocuklar anne-babalarından örnek alarak öğrenebilirler. Kaza gibi korkutucu olaylar yaşarlarsa koşullanma ile öğrenebilirler. Ayrıca çok kontrol edici ve aşırı koruyucu aile tutumları da çocuklarda kaygı bozukluğuna neden olabilmektedir (Bahalı ve diğ., 2009; Öztürk ve Uluşahin, 2011; Kring ve diğ., 2014)

Öğrenci ve veli değerlendirmeleri karşılaştırıldığında yalnızca depresyon alt testinde istatistiksel olarak anlamlı bir farklılık görülmüştür. Kendilerinin depresyonda olduğunu belirten öğrencilerin velilerinin tümü, çocuklarını depresyon açısından normal olarak değerlendirmektedirler. Kauffman ve Landrum (2015) depresyon ile kaygı bozukluklarının aynı anda olabildiğini ve binişiklik gösterdiğini vurgularlar. Depresyon okul çocuklarının \%23'ünde genellikle rastlanan bir rahatsızlıktır ve cinsiyet açısından farklılık görülmemektedir (Kring ve diğ., 2014). Depresyondaki velilerin çocuklarında da depresyon görülme olasılığı yüksektir (Nolen-Hooksema, 2011).

\section{Depresyon alt ölçeğinde öğrenci ve veli algılarının karşılaştırılması}

\section{TABLO 5}

Veli - Öğrenci Depresyon Alt Ölçeği Değerlendirmelerinin Wilcoxon İşaretli Sıralar Testi Sonuçları

\begin{tabular}{lccccc}
\hline Veli- Öğrenci & $\mathrm{n}$ & Sira Ort. & Sıra Top. & $\mathrm{Z}$ & $\mathrm{p}$ \\
\hline Negatif Sıra & 4 & 6.5 & 26 & $-2.878^{*}$ & .004 \\
Pozitif Sıra & 15 & 10.93 & 164 & & \\
Eşit & 101 & & &
\end{tabular}


*Negatif sıralar temeline dayalıdır

Öğrencilerin kaygı ve depresyon düzeylerine tüm alt ölçekler ve genel toplamlar açısından Spearman Korelasyon katsayısı uygulandığında, öğrenciler ile velilerin değerlendirmeleri arasında herhangi bir ilişki/korelasyon bulunamamıştır. Örn: Fobi (7) ve depresyon (13) bozukluğu bildiren öğrencilerin velilerinin tümü, çocuklarında hiçbirşey olmadığını belirtmişlerdir.

Sonuçta, veliler çocuklarının davranışlarını yalnızca kendi gözlemleri doğrultusunda değerlendirmekte olabilirler. Aile tutumları ve yakın çevreyle etkileşim sonucunda oluşan benlik saygısının düşüklüğü psikopatoloji ile bağlantılıdır ve pek çok rahatsızlığa yol açabilir (Sümer ve diğ., 2009). Ayrıca kaygı bozuklukları çeşitlerinin, OKB, ve depresyonun eş zamanlı olarak görülme olasılıkları yüksektir (Kauffman ve Landrum, 2015). Bu bağlamda çocuk ruh sağlığında çalışanların tanı koyarken çoklu bilgi kaynaklarından yararlanmaları gerekli ve önemlidir (Özcan ve Aysev, 2009).

\section{Sonuç ve öneriler}

Velilerin öğrencileri değerlendirmelerinde, kızlar ve erkekler açısından anlamlı bir farklılık bulunmamaktadır. Fakat yüksek kaygı düzeyinde kızlarla erkeklerin duyumsadıkları kaygı oranlarının erkekler aleyhine yüksek olması, ailelerinin ve öğretmenlerin erkek öğrencilerden beklentilerinin, kültürel ögeler nedeniyle yüksek olduğuna işaret ettiği şeklinde yorumlanabilir

Erkek çocukların velileri, genellikle çocukların kendilerinde algıladıkları kaygı, fobi, panik, OKB, depresyon gibi rahatsızlıkları toplam kaygı ve toplam kaygı-depresyon durumlarını da çocuklarından daha az olarak algılarken kız çocukların velileri daha fazla olarak algılamaktadırlar.

OKB, hem kızlarda hem erkeklerde diğerlerine göre göreceli olarak yüksektir ve bu hem çocuklar hem de veliler tarafından farkedilmiştir. Öğrencilerde yaygın olarak görülen OKB, belirtileri başka bozukluklarla benzerlik gösterdiği için tanısı zor olan bir rahatsızlık olarak kabul edilir. Oysa büyüklerin çocuklara anladıkları yaştan itibaren mikrop kapıp hastalanmamaları için sürekli uyarıda bulunmaları, OKB rahatsızlığı için uygun zemin hazırlamakta olabilir.

Çocukların yaşadıkları depresyonu velilerinin farketmemelerinin nedeni, kaygı bozuklukları, OKB ve depresyon belirtilerinin birbirlerine benzemesi ile açıklanabilir. Araştırmanın yapıldığı bölgedeki ailelerin sosyo-ekonomik-kültürel düzeyleri orta ve ortanın 
altında olduğundan çocuklar depresyonu, ailede yaşanan olaylara velilerinin verdikleri tepkileri örnek almak yoluyla da yaşamakta olabilirler.

Her iki grupta da sınırda kaygı düzeyine sahip olan öğrencilerin oranları göreceli olarak alanyazındaki oranlarla örtüşmekte olsa da, bu öğrencilerin ergenlik çağına gelmeden önce rehberlik servisinden bireysel ve/veya grup çalışmaları şeklinde psikolojik destek almaları sağlıklı gelişimleri için önemli görülmektedir.

Türkiye'de çocuklarda kaygı bozukluklarına ilişsin doğrudan araştırmalar sınırlı sayıda ve klinik düzeydedir. Daha çok sosyal kaygı, zorbalığa maruz kalma, anne-baba tutumları konularında yapılan dolaylı araştırmalar bulunmaktadır. Kaygı bozukluklarına ilişkin araştırmaların özellikle okullarda artması, öğrencilere profesyonel yardımın gecikmeden verilmesini sağlayacak ve toplum sağlığına dolaylı olarak katkıda bulunabilecektir.

\section{Araştırmanın Alan Yazına Katkısı :}

- İlkokul öğrencilerinin kendi içlerinde yaşadıkları ve farkında oldukları sıkıntılarına dikkat çekerek, okullarda velilere yönelik bilgilendirme çalışmalarının yapılmasının önemine değinmek

- Velilerin çocukları tanımalarına ve anlamalarına yardımcı olmak

- İlkokulda başlayan rahatsızlıkların tedbir alınmazsa daha üst sınıflarda artarak öğrencilerin günlük yaşamlarını etkileyebileceğinin farkedilmesini sağlamak

- İlkokul, ortaokul ve liselerde yapılacak benzer çalışmalara kaynak oluşturmak

- Türkiye'deki çocuklarda kaygı bozuklukları konusunda ihtiyaç duyulan alan araştırması ile alanyazına katkıda bulunmak

\section{Kaynaklar}

Akgün, N. (1989). Obsesyonel nevroz saplantı-zorlantı bozukluğu, İstanbul: Nobel Tıp.

Ankay,A. (2013) Ruh să̆glı̆ı ve davranış bozuklukları. İstanbul: Nobel Tıp.

Arkonaç, O. (1989). Acil psikiyatri, İstanbul: Nobel Tıp

Austin, V.L. ve Sciarra, D.T. (2012). Çocuk ve ergenlerde duygusal ve davranışsal bozukluklar, M.Özekes (Ed.), Ankara: Nobel.

Bahalı,K., Tahiroğlu,A.Y., Avcı,A. (2009).Okul reddi olan çocuk ve ergenlerin klinink özellikleri. Anatolia Journal of Psychiatry 2009,10:310-317

file:///C:/Users/Lenovo/Downloads/Okul_reddi_olan_cocuk_ve_ergenlerin_klinik_ozellik.pdf

Baştürk, R. (2011). Bütün yönleriyle SPSS örnekli nonparametrik istatistiksel yöntemler. 
Ankara: An1.

Bourne,E.J. (2010). The anxiety \& phobia workbook. ABD: New Harbinger.

Butcher, J.N., Mineka,S.ve Hooley,J.M. (2013) Anormal Psikoloji. İstanbul: Kaknüs

Büyüköztürk, Ş. (2006) Sosyal bilimler için veri analizi el kitabı. Ankara: Pegem

Büyüköztürk, Ş., Çakmak, E.K., Akgün,Ö.E., Karadeniz,Ş., Demirel,F.(2011). Bilimsel araştırma yöntemleri. Ankara: Pegem Akademi.

Corey,G. (2005). Psikolojik danışma, psikoterapi kuram ve uygulamaları. Ankara: Mentis

Demir,T., Eralp-Demir, D., Türksoy,N.,Özmen,E. ve Uysal,Ö. (2000) Çocuklar için sosyal anksiyete ölçeğinin geçerlik ve güvenilirliği. Düşünen Adam, 13 (1): 42-48

http://www.dusunenadamdergisi.org/ing/dergipdf/dusunen_adam_dergisi_24afead7f9814ed69

5977a1fc21d1213.pdf

DSM-4 (2000). Amerikan Psikiyatri Derneği . DSM-4 Tanı Ölçütleri. Ankara: HYB ve Boylam Psikiyatri Enstitüsü.

DSM-5 (2013). Amerikan Psikiyatri Derneği. DSM-5 Tanı Ölçütleri. Ankara: HYB ve Boylam Psikiyatri Enstitüsü.

Ertürk, Y.D. ve Gül, A.A. (2006). Çocuğunuzu televizyona teslim etmeyin. Ankara: Nobel.

Görmez,V.Kılıçaslan,A.Ebesutani, C. (2017). Psychometric properties of the parent version of the revised child anxiety and depression scale in a clinical sample of Turkish children and adolescents. Child Psychiatry Human Development. 2017, 48 (6): 922-933.

Güleç, C. (2006) Psikiyatrinin A-B-C'si. İstanbul: Say.

Karasar, N.(2000). Bilimsel araştırma yöntemi. Ankara:Nobel

Kauffman,J.M. ve Landrum,T.J.(2015). Dugusal ve davranışsal bozukluğu olan çocukların ve gençlerin özellikleri. Ankara: Nobel

Kring,A.M., Johmson,S.L., Davison,G. Ve Neale,J. (2014). Abnormal psychology. Singapure: Wiley

Manassis,K. ve Monga,S. (2001). A therapeutic approach to children and adolescents with anxiety disorders and associated comorbid conditions. Child \& Adolescent Psyciatry, January 2001, Volume 40, Issue 1, pp:115-117. https://www.jaacap.org/article/S0890$\underline{8567(09) 60823-6 / a b s t r a c t}$

Mukaddes, N.M. (2001). Çocukluk ve ergenlik çağı obsessif kompulsif bozukluğu. (Ed) Prof.Dr.Özgür Polvan. Çocuk ve Ergen Psikiyatrisi.(s.135-141) İstanbul: Nobel Tıp

Murdock,N.L. (2014). Piskolojik danışma ve psikoterapi kuramları. Olgu sunumu yaklaşımıyla, Füsun Akkoyun (Çeviri Ed.), Ankara: Nobel 
Nolen-Hoeksema, S. (2011). Abnormal psychology. NY: McGraw-Hill International Edition.

Özcan,Ö. Ve Aysev,A. (2009). Okul fobisi olan çocuklarda araştırılması, İnönü Üniversitesi Tıp Fakültesi Dergisi, 16 (1): 13-17. http://dergipark.ulakbim.gov.tr/totmd/article/view/5000100391

Özcan,Ö., Kılıç,B.G. Aysev,A. (2006). Okul korkusu yakınması olan çocukların ana babalarında ruhsal bozukluklar, Türk Psikiyatri Dergisi, 2006;17 (3):173-180. http://www.turkpsikiyatri.com/C17S3/okulKorkusu.pdf

Öztürk,O. Ve Uluşahin, A. (2011). Ruh sağlığı ve bozuklukları I. Ankara: BAYT ve Nobel Tip.

Seçer,İ. (2013). SPSS ve Listrel ile pratik veri analizi. Ankara: Anı

Seçer,İ ve Gülbahçe,A. (2013). Çocuklarda anksiyete duyarlılık ölçeğinin Türk kültürüne uyarlanması: Güvenirlik ve geçerlik çalışması. Middle Eastern \& African Journal of Educational Research, İssue: 3 s.91-106 https://s3.amazonaws.com/academia.edu.documents/31361594/Adaptation_of_the_An xiety_Sensitivity_Index_for_Children_to_Turkish_The_Study_of_Validity_and_Relia bility.pdf?AWSAccessKeyId=AKIAIWOWYYGZ2Y53UL3A\&Expires=1530352949 \&Signature $=\mathrm{tUq} 8 \mathrm{UfKejwu0Dr7UgR61jgVcUbI \% 3D \& response-content-}$ disposition=inline \%3B\%20filename\%3DAdaptation_of_the_Anxiety_Sensitivity_In.p $\underline{\mathrm{df}}$

Sümer, N., Ünal,S., Selçuk,E., Kaya,B., Polat,R., ve Çekem,B. (2009). Bağlanma ve psikopatoloji: Bağlanma boyutlarının depresyon, panik bozukluk ve obsesif-kompolsif bozuklukla ilişkisi, Türk Psikoloji Dergisi, Haziran 2009, 24 (63):38-45. https://search.proquest.com/openview/2680c045e421e1d10eb7b151a7762ee6/1?pqorigsite $=$ gscholar $\& \mathrm{cbl}=28562$

Yaluğ, İ., Kocabaşoğlu, N., Aydoğan, G., Günel, B. (2003). Obsesif kompolsif bozukluk ve panik bozuklukta depresyon ve kişilik bozukluğu komorbiditesi, Düşünen Adam, 2003, 16 (1): 28-34. http://www.dusunenadamdergisi.org/Ing/DergiPdf/DUSUNEN_ADAM_DERGISI_5d 29742e984345b1a2df384b9a131c67.pdf

Yalom, I. (1999). Varoluşcu psikoterapi, İstanbul: Kabalc1.

Yurdabakan,İ (2009). Grup rehberliği programının ilköğretim sekizinci sınıf öğrenccilerinin sınav kaygı düzeylerine etkisi. Serdar Erkan ve Alim Kaya (Editörler). Grupla psikolojik danışma ve rehberlik programları I. Ankara: Pegem Akademi

Yüksel, N. (2006). Ruhsal hastalıklar. Ankara: MN Medikal ve Nobel 